\title{
Integrating Structural and Non-structural Flood Management Measures for Greater Effectiveness in Flood Loss Reduction in the Kelantan River Basin, Malaysia
}

\author{
Ngai Weng Chan, Aminuddin Ab Ghani, Narimah Samat, \\ Nik Norma Nik Hasan and Mou Leong Tan
}

\begin{abstract}
The state of Kelantan in Malaysia is a flood-prone state exposed to seasonal Monsoon rains that bring seasonal floods resulting in significantly losses. Flood management in the state is modelled after the country's predominant government-centric top-down approach focused on flood-control technologies via structural measures such as multi-purpose dams, levees, embankments, tidal gates, diversion channels and others. These structural measures do not engage the public who fail to understand the measures leading to lack of confidence, misunderstanding and mistrust. This results in ineffectiveness of the measures leading to greater flood losses. In contrast, local communities are familiar with non-structural measures which they have long used to adapt to floods. These measures are also relatively simple, cost-effective and easily implementable over a short period of time. Both measures, however, must engage the public/victims in all phases of the flood disaster cycle. Balancing both types of flood management measures is the key to more effective management. A combination of structural and non-structural measures is the way forward for Kelantan State as it ensures that government structural measures are effectively supported by public-engaged non-structural measures.
\end{abstract}

Keywords Structural flood management - Non-structural flood management • Flood warning · Public engagement - Flood loss reduction

N. W. Chan $(\bowtie) \cdot$ N. Samat $\cdot$ M. L. Tan

Geography Section, School of Humanities, Universiti Sains Malaysia (USM),

11800 Penang, Malaysia

e-mail: nwchan@usm.my

A. A. Ghani

River Engineering and Urban Drainage Research Centre, Universiti Sains Malaysia,

11800 Penang, Malaysia

N. N. N. Hasan

School of Communications, Universiti Sains Malaysia (USM), 11800 Penang, Malaysia

(C) Springer Nature Switzerland AG 2020

F. Mohamed Nazri (ed.), Proceedings of AICCE'19, Lecture Notes in Civil

Engineering 53, https://doi.org/10.1007/978-3-030-32816-0_87 


\section{Introduction}

Located in the east coast of Peninsular Malaysia, Kelantan State is historically a flood-prone state because of its seasonal exposure to Monsoon winds, as well as its low-lying topography on floodplains and the location of dense populations and settlements near rivers [1, 2]. The state is plagued by seasonal Monsoon floods that affect almost the entire state, resulting in significant annual flood losses, including loss of lives [3]. The annual flood losses in terms of loss of lives, crop losses and economic losses is severe [4]. Kelantan, as is Malaysia, has a long history of flood disasters dating back to 1926 due to its exposure to heavy seasonal monsoon rains. The state is made up of low-lying topography with large tracts of flat floodplains and drained by large rivers, resulting in more than a quarter of the state being flood-prone [3]. In Kelantan, agriculture is a main economic activity and seasonal flooding is considered good for padi cultivation. Padi fields are also good retention ponds for flood waters. In the padi areas affected by seasonal flooding, the local communities live in harmony with floods and are able to cope reasonably well [5]. However, people in the urban areas are not so exposed to seasonal flooding and are ill-prepared for it. In recent decades, Kelantan has developed both its upstream and downstream regions. The upstream regions have been deforested both for logging and vegetable farming. Due to rapid landuse change, most notably from deforest to agriculture or urban landuse, the hydrological regime has been compromised and this has been a factor that has exacerbated flooding [6]. Consequently, in urban areas, the occurrence of flash floods is considered a sign of unsustainable development [7]. Elsewhere in Malaysia, this is also happening where rapid development of urban floodplains in the large cities of Kuala Lumpur, George Town and Kota Bharu has exacerbated flooding [8]. Over time, the replacement of rain-absorbent natural forests with impervious surfaces has resulted in accelerated runoff entering the rivers in a short period of time. Siltation has also reduced the drainage capacities of most rivers. Furthermore, river encroachment is occurring in urban areas as built-up areas come very close to river banks resulting in constriction of rivers. This leads to destruction of river reserves and the buffer zone is destroyed. In Kelantan, a combination of rapid urbanisation, upstream deforestation and sedimentation has significantly altered the hydrological regime, leading to more runoff entering the rivers in a short time. Significantly, flood peaks are also higher due to larger volumes of runoff [9].

In the area of flood management, Kelantan State follows closely the country's predominant official response strategy which is based on a lop-sided technology-centred approach via the use of structural flood control measures [10]. In developed countries, such structural measures when applied prudently can reduce flooding and flood loss [11]. However, the application of structural measures addresses only the technical aspects of floods. Moreover, these measures can only be successful if the public/victims have confidence and respond correctly to them [12]. For example, when high-tech structural flood measures are imported without consideration of the local circumstances, they may not be compatible or not 
acceptable to local communities. Hence, this can reduce their effectiveness. In contrast, non-structural measures are more pro-active and easy to apply and understand. Such measures result in better responses in times of flooding resulting in reduction of flood losses. These measures are also relatively cost-effective, require a short time to implement and supplement structural measures well. The use of these measures underlines the importance of non-structural flood measures vis-àvis the structural strategies. Non-structural measures engage the people/victims as they are involved sufficiently in all the phases of the flood disaster cycle. A combination of structural and non-structural measures is the way forward, as this ensures that government structural measures are effectively supported by public-engaged non-structural measures, both working in tandem to maximise flood-loss reduction [13]. In another study, Jamrussri and Toda [14], simulated past severe flood events in the upper Chao Phraya River Basin in Thailand, and found that non-structural flood countermeasures are more effective than structural measures.

\section{Methods}

The study area is in the Kelantan River basin. The methodology is based on: (1) Primary Data- (a) Quantitative Survey of households affected by floods and (b) Qualitative Interviews with Key Stakeholders; (2) Secondary Data-Historical Flood Data, theses, government reports, other reports. (3) Observer-Participant method. This study therefore adopts a multi-methods approach whereby a combination of complementary research methods are used to support one another. Historical analysis is used for documentation of past floods in terms of frequency, magnitude and severity. As an 'Observer-participant', the author himself is well positioned to as a researcher with rich experience, having worked in the flood management area for more than 30 years. The 'observer-participant' is used in the analysis of key stakeholders on their views on flood management. The quantitative questionnaire is employed to study individual perception, understanding, response and evaluation of existing measures of flood management. Purposive sampling based on the researcher's expert knowledge and judgment of the flooded areas in Kelantan was used. This type of sampling is selective and subjective in nature whereby the sampling technique relies solely on the researcher's own judgment when choosing the respondents. Purposive sampling is a non-probability sampling method suitable for a first time survey of respondents in a disaster area where accessibility is problematic and infrastructure and houses are damaged beyond recognition. The accuracy of this type of sampling is largely dependent on the researcher's experience and knowledge of the affected area and the respondents. With adequate experience and knowledge, researchers believe that they can obtain a fairly representative sample by purposive sampling which also saves time and money. Qualitative indepth interviews are also recorded with selected flood victims. 
Table 1 Sample of respondents by site in Kelantan

\begin{tabular}{l|c|c}
\hline Sampling site & Number of respondents & Percent \\
\hline Jalan Bayam, Kota Bharu & 8 & 6.7 \\
\hline Jalan Pengkalan Chepa, Kota Bharu & 16 & 13.4 \\
\hline Kampung Kasar, Pasir Mas & 22 & 18.5 \\
\hline Padang Tembak, Kota Bharu & 4 & 3.4 \\
\hline Pinggir Tapang, Kota Bharu & 6 & 5.0 \\
\hline Tapang, Kota Bharu & 12 & 10.1 \\
\hline Teluk, Kota Bharu & 15 & 12.6 \\
\hline Tendung, Pasir Mas & 36 & 30.3 \\
\hline & 119 & 100.0 \\
\hline
\end{tabular}

In this study, a questionnaire-based cross sectional study was conducted by convenience sampling at locations in Kelantan State (Table 1). The total number of respondents interviewed was 119 .

\section{Discussion of Results}

\subsection{Structural Versus Non-structural Flood Mitigation Measures}

In Kelantan, the public expect the government is to be responsible for all aspects of flood protection. Hence, not surprisingly, most government flood mitigation schemes are based on the structural approach. Nevertheless, in the flood-prone areas of Kelantan State, people have lived with floods for centuries and have developed a myriad of non-structural flood adaptation measures [15]. These include using green absorptive surfaces, retention ponds, padi fields, flood warning systems, landuse control, legislation, flood risk mapping, enforcement and others [16, 17]. In the current study, it was found that the majority of flood victims believed that structural measures were either effective or somewhat effective (Table 2). Only a small minority of flood victims during the 2014 flood in Kelantan were of the opinion that the that structural measures were ineffective. This could have been either due to their ignorance, poor awareness or "blind belief" in their support of government structural flood mitigation schemes. Flood victims in Kelantan are also highly dependent on government flood aid. Hence, most of them would believe in government flood schemes. These results were similar to those found by Chan et al. [18] who found that the role of citizen science in using non-structural measures to cope with flood disasters were more important in recovery in Malaysia.

Despite the heavy dependence on structural methods used by the Kelantan State Government for flood control, many areas are still vulnerable to floods, leaving a significant number of people to fend for themselves. Not surprisingly, many flood 
Table 2 Respondents' view of the effectiveness of structural measures in Kelantan

\begin{tabular}{l|l|l|l|l|l}
\hline Gender & \multicolumn{2}{|l|}{ Effectiveness of structural measures in flood control } & Total \\
\cline { 2 - 5 } & $\begin{array}{l}\text { Very } \\
\text { effective }\end{array}$ & $\begin{array}{l}\text { Somewhat } \\
\text { effective }\end{array}$ & $\begin{array}{l}\text { Not } \\
\text { effective }\end{array}$ & $\begin{array}{l}\text { No comments/don't } \\
\text { know }\end{array}$ & \\
\hline Male & 30 & 56 & 9 & 2 & 97 \\
\hline Female & 10 & 10 & 2 & 0 & 22 \\
\hline Total & 40 & 66 & 11 & 2 & 119 \\
\hline
\end{tabular}

Table 3 Respondents' view on the effectiveness of non-structural measures in Kelantan

\begin{tabular}{l|l|l|l|l|l}
\hline Gender & \multicolumn{3}{|l|}{ Effectiveness of non-structural measures in flood control } & Total \\
\cline { 2 - 6 } & $\begin{array}{l}\text { Very } \\
\text { effective }\end{array}$ & $\begin{array}{l}\text { Somewhat } \\
\text { effective }\end{array}$ & $\begin{array}{l}\text { Not } \\
\text { effective }\end{array}$ & $\begin{array}{l}\text { No comments/don't } \\
\text { know }\end{array}$ & \\
\hline Male & 50 & 29 & 11 & 7 & 97 \\
\hline Female & 12 & 7 & 3 & 0 & 22 \\
\hline Total & 62 & 36 & 14 & 7 & 119 \\
\hline
\end{tabular}

victims have become "flood-wise" and have developed some forms of flood mitigation and flood-loss reduction methods [1]. The amount of flood loss-reduction resulting from the use of traditional non-structural methods of flood mitigation has been shown to be significant [4]. Table 3 shows the respondents' view on the effectiveness on non-structural measures to reduce flood loss. This underlines the importance of non-structural flood response as a supplementary flood strategy. It should also be noted that community flood resilience is vital in helping victims recover and to be self-reliant, especially via the role of social capital in flood recovery [19]. Social capital is a form of non-structural flood strategy.

In Kelantan, the predominant official flood management strategy is still focused in using structural flood control measures. Over the decades since independence in 1957, the Malaysian Government has spent a huge amount of its annual budget on structural flood measures [20]. Despite the huge amount of funds invested on such mega structural measures, flood disasters continue to escalate. In recent decades flood disasters have exacerbated many folds due to a combination of climate change and human mis-management of the physical systems such as forests, rivers, wetlands and landuse [21]. In contrast, it is increasingly obvious that flood victims have evolved many effective non-structural measures to reduce flood losses as well as to adapt and "live with" floods. Therefore, a comprehensive method employing both structural and non-structural measures would be hugely beneficial. However, politics and economic considerations often reduce the application of non-structural measures and this has severely curtailed the overall effectiveness of flood management in Malaysia [8]. 


\subsection{Government-Centric Structural Flood Mitigation Measures}

The Malaysian Government Agency in charge of flood management is the Drainage and Irrigation Department (DID) Malaysia which is traditionally an engineering organization run by engineers. Chan [22] has documented in detail the many structural measures currently employed by the DID to manage floods in Malaysia. Some major structural measures are as follows: (i) River Improvements. This involves dredging, widening, straightening and deepening river channels to encourage swift flow and maintain drainage capacities. River embankments are also built to control bank erosion and this reduces sedimentation which affects the drainage capacities of rivers. (ii) Tidal Gates. These gates are effective on small rivers and can serve both as a barrier to high tide as well as to control salt water intrusion and irrigation. Tidal gates in Kelantan are used extensively across many river mouths and are effective for controlling both tidal and fluvial flooding. (iii) Urban Drainage Systems. These drainage systems in cities are often modelled as sustainable urban drainage systems (SUDSs). A good example is the Universiti Sains Malaysia Engineering Campus in Penang which is built on such a system [8]. The SUDS not only reduces flooding but also filters stormwater to ensure better water quality. It is also aesthetically better looking, safer for the public and provides recreational facilities. The drainage capacities of urban drains in cities and towns can be improved by widening, deepening and enlarging the existing network. The DID has developed a new flood management approach focusing on retention of rainwater at source based on the Urban Drainage Manual known as Storm Water Management Manual for Malaysia (MSMA). The MSMA is a soft-engineering method which is built into the surrounding landscape and environment. It is also environmentally friendly and safe (as there are no open drains). As such, the MSMA can even be considered as a combination of semi-natural non-structural measure, even though some minor construction of underground drainage and retention ponds are carried out. As a complement to the MSMA, the River Engineering and Urban Drainage Research Centre in Universiti Sains Malaysia has introduced the innovative the "Bio-Ecological Drainage System (BIOECODS)" [23, 24]. (iv) Diversion or Relief Channels. These channels are usually constructed upstream of frequently flooded areas to channel away part of the flow. The channels can be closed at normal flow but can be opened during high flows to siphon off a substantial amount of discharge elsewhere. Relief channels allow excess water to be drained away, thus averting flooding. Such channels can drain a substantial volume of discharge and relieve pressure on main rivers. The SMART Tunnel built was built to reduce flooding in the capital city of Kuala Lumpur [25]. (v) Underground Drainage. These are underground drains that are built in areas where there is lack of surface land to build surface drainage systems. However, it is problematic in a flood-prone area where it is often waterlogged. These drains are also substantially more expensive compared to surface drains or SUDSs. (vi) Retention Ponds. These ponds have become popular in recent decades. They are usually built beside 
flood-prone rivers to siphon off some of the excess water as low-lying areas along rivers can be easily converted into retention ponds which siphon off excess river discharge during high flows. During the dry season or normal times, these ponds are usually dry and can double up as playing fields or used as lakes for water sport/ recreation. In some cases, aquaculture can be carried out in such ponds to generate income for local communities. (vii) Water Pumps. These are usually installed in highly flood-prone areas that are constantly water-logged. They can be operated manually or automatically via telemetry when the river water level rises to a certain pre-determined critical level. In some permanently waterlogged areas, pump houses can be built. These pump houses can be connected to canals that can drain directly into the river, lake or sea. (viii) Multi-purpose Dams. Dams, especially the multi-purpose dams, have become very popular in Malaysia [26, 27]. Such dams have been known to be effective in flood control. For example, after Kenyir Dam was built in Terengganu, it effectively reduced much of the flooding downstream of the Terengganu river [28]. In Kelantan, there has been some suggestion to build a multi-purpose dam upstream of the Kelantan river to control flooding. However, dams are expensive and cause a great deal of environmental problems. Dams also have a life span and pose serious dangers to downstream populations, both humans and others [29]. (ix) Flood-Proof Buildings. This measure has been historically adopted by flood-prone communities in Kelantan. It has also been found to be highly successful in many Asian countries. Flood-proofing of properties, public and private, is effective in reducing flood loss. In Malaysia, the traditional Malay stilt-house is a good example of a flood-proofed property. Many apartments and flats can be flood-proofed by having a ground floor only for parking. Government buildings can also be made flood-proofed. The Rumah Rakit or "Raft House" is also a form of flood-proofing of a property. It is found in abundance along the Kelantan river [30]. (x) Levees or Bunds. These are structures constructed with earth, stones, concrete, cement and other materials built along both sides of a river. Levees or bunds have been used extensively along the coast in many countries to prevent coastal flooding as well as along rivers to prevent river flooding [31]. In the world, the most famous country using bunds and levees (dikes) to protect itself from sea flooding is Holland. Holland has successfully adopted this structural method of flood control effectively [32]. In Kelantan, levees and bunds were initially built to keep out the sea, and to reclaim land from the sea for agricultural purposes. In recent decades, however, frequent river flooding has necessitated the construction of levees in many urban as well as rural areas for flood protection. Some notable examples of bunds built along rivers are found in Pekan (on the Pahang River) and Teluk Intan (on the Perak River). Table 4 shows the overall rating of the effectiveness of various structural measures by flood victims in Kelantan. While most respondents rated these measures as effective, a significant number also rated them not effective. This shows that the structural measures are not convincingly effective in the eyes of the people affected. 
Table 4 Rating of the effectiveness of various-structural measures in Kelantan

\begin{tabular}{l|l|l|l|l|l}
\hline Flood measure & $\begin{array}{l}\text { Very } \\
\text { effective }\end{array}$ & $\begin{array}{l}\text { Somewhat } \\
\text { effective }\end{array}$ & $\begin{array}{l}\text { Not } \\
\text { effective }\end{array}$ & $\begin{array}{l}\text { No comments/ } \\
\text { don’t know }\end{array}$ & Total \\
\hline $\begin{array}{l}\text { River } \\
\text { improvement }\end{array}$ & 50 & 19 & 40 & 10 & 119 \\
\hline Tidal gate & 48 & 17 & 43 & 8 & 119 \\
\hline Urban drainage & 45 & 20 & 39 & 15 & 119 \\
\hline $\begin{array}{l}\text { Diversion } \\
\text { channel }\end{array}$ & 43 & 23 & 41 & 12 & 119 \\
\hline Retention pond & 49 & 18 & 44 & 8 & 119 \\
\hline Water pump & 39 & 20 & 45 & 15 & 119 \\
\hline Dam & 52 & 22 & 36 & 9 & 119 \\
\hline $\begin{array}{l}\text { Flood-proof } \\
\text { building }\end{array}$ & 33 & 25 & 45 & 16 & 119 \\
\hline Levee/bund & 49 & 26 & 37 & 7 & 119 \\
\hline
\end{tabular}

\section{People-Centric Non-structural Flood Coping Measures}

Ironically, long before governments became important and in the modern era, the communities had developed various strategies to fend for themselves in the face of floods. The public does not have the funds or the know-how to implement structural schemes. Hence, they sought to implement mostly non-structural measures of flood reduction which are essentially those measures that do not require the construction of large artificial structures that are damaging to the environment and natural ecosystems. Non-structural measures are less expensive than structural ones (which usually need heavy capital expenditure) and can be used to supplement existing structural measures. Non-structural measures are also more sustainable [33]. Non-structural measures are usually environmentally friendly and are built so that they blend in with the environment and make use of environmental attributes (for example using existing wetlands as retention ponds rather than constructing artificial concrete-lined ponds) can also be quickly implemented as compared to the construction of dams and reservoirs which may take years [14]. Some notable non-structural measures which can be applied effectively are as follows:

(i) Legislation. Laws and regulations can be used to control flooding because they can regulate land use, development and deforestation. In Kelantan, there are many Malaysian laws relating to flood control but none of them deal directly with flood protection or flood control. There is currently no Flood Act, Flood Enactment or River Law which can deal directly with flood protection and control [34]. Furthermore, in relation to legislation, Chan [22] has noted that the Drainage and Irrigation Department (DID) has very little power when it comes to passing or rejecting a development project that has a flood component. Laws relating to the gazettement of forest reserves, river reserves and parks are necessary since they affect floods. Deforestation has probably played a major part in the huge flood of 
2014 in Kelantan [35]. (ii) Public Education and Awareness Campaigns. Engaging the public, especially the flood victims, can effectively help to reduce flood losses. Flood preparedness and readiness to respond correctly and in a timely manner is crucial in reducing loss of lives and properties. Flood victims must be made aware of how the warning system works and how to respond to them. Flood awareness, flood education, flood preparedness, and flood warning and evacuation programmes must be communicated to the people on a regular basis. (iii) Relocation of Riverine Communities. A significant number of Kelantanese people live on the banks of rivers, on floodplains or near to rivers. There are also many squatters living on these flood-prone areas. Many flood mitigation schemes are delayed because riverine residents refused to move out as they cause problems in land acquisition and resettlement of affected residents. (iv) Gazettement of Green Belts. Green belts such as river reserves, buffer zones and riverine flora should be maintained for various reasons, including flood reduction. Government should make it mandatory for developers to maintain green belts or green zones in development areas. For example, for a development project to be passed, it should have a mandatory green belt of grass and other vegetation to absorb rainwater. Developers should reserve at least a third of the developed area for parks and vegetation, irrespective of whether it is industry, housing, commercial lots or other land uses. (v) Environmental Impact Assessment (EIA). EIA should be made mandatory for all developments in areas considered flood prone. Furthermore, Macro EIAs should be enforced in highly flood-prone or environmentally sensitive areas. Macro EIAs ensure environmental effects are addressed not only in the development area but also downstream and other adjacent areas. EIA consulting companies should not be appointed by developers but by the government. (vi) Flood Forecasting. In Kelantan, the flood forecasting systems currently employed are outdated. The forecasting system is still using telemetric rainfall and river level data, but these can only detect the rainfall once it has reached the gauges or the river, resulting in less time to issue effective warning. In developed countries, real-time state-of-the-art flood forecasting systems are employed using computer modelling that runs on radar or satellite estimated rainfall. Using these remotely sensed rainfall data, the rainfall is forecast before it reaches the ground and the river. This will provide the forecaster ample time for the issuance of a flood warning. (vii) Flood Warning Systems. A good flood warning system saves lives. Chan [1] has shown that the existing flood warning systems in Kelantan are largely inadequate and should be upgraded.

Table 5 shows the overall rating of the effectiveness of various non-structural measures by flood victims in Kelantan. Most respondents rated these measures as effective rather than not effective. This shows that the public have confidence in non-structural measures which they are familiar with as they have been using these strategies for decades. These measures are also simple and easy to understand. Non-structural strategies appear convincingly effective in the eyes of the people affected. 
Table 5 Respondents' rating of the effectiveness of non-structural measures in Kelantan

\begin{tabular}{l|l|l|l|l|l}
\hline Flood measure & $\begin{array}{l}\text { Very } \\
\text { effective }\end{array}$ & $\begin{array}{l}\text { Somewhat } \\
\text { effective }\end{array}$ & $\begin{array}{l}\text { Not } \\
\text { effective }\end{array}$ & $\begin{array}{l}\text { No comments/ } \\
\text { don't know }\end{array}$ & Total \\
\hline Legislation & 55 & 25 & 19 & 20 & 119 \\
\hline $\begin{array}{l}\text { Education/ } \\
\text { awareness }\end{array}$ & 53 & 23 & 24 & 19 & 119 \\
\hline Relocation & 54 & 24 & 26 & 15 & 119 \\
\hline Green belt & 62 & 23 & 20 & 13 & 119 \\
\hline EIA & 60 & 14 & 30 & 5 & 119 \\
\hline $\begin{array}{l}\text { Flood } \\
\text { forecasting }\end{array}$ & 56 & 20 & 37 & 6 & 119 \\
\hline Flood warning & 55 & 19 & 33 & 12 & 119 \\
\hline Flood-proofing & 59 & 30 & 13 & 17 & 119 \\
\hline Levee/bund & 65 & 26 & 18 & 10 & 119 \\
\hline
\end{tabular}

\section{Conclusion}

This paper examined the views of flood victims on the effectiveness of structural and non-structural measures of flood management. It also highlights the current lop-sided approach in using structural measures by the government flood authorities. This is considered a deficiency of the current practices, and it is suggested that improvements should adopt a comprehensive approach combining both structural and non-structural measures to complement each other. Results from this paper indicate that the current flood management approach in Kelantan is ineffective and needs to shift from a one that is over-focused on structural measures to a comprehensive approach combining both structural and non-structural measures.

Acknowledgements The authors would like to acknowledge the FRGS Research Grant 203. PHUMANITI.6711693 which supported the research that culminated in the publication of this paper.

\section{References}

1. Chan NW (1995) A contextual analysis of flood hazard management in Peninsular Malaysia. Flood Hazard Research Centre Publication no. 267, Enfield (UK)

2. Winstedt RO (1927) The great flood, 1926. J Malayan Branch R Asiatic Soc V(II):295-309

3. Ismail WR, Haghroosta T (2018) Extreme weather and floods in Kelantan state, Malaysia in December 2014. Research in Marine Sciences, vol 3, no 1, pp 231-244

4. Chan NW, Mahamud KRBK, Karim MZA (2016) Assessing different types of flood losses in Kelantan State in Malaysia during the december 2014 flood. In: Proceedings of the 1st international conference on society, space \& environment

5. Chan NW, Zakaria NA, Ghani AA, Lee LK, Samat N (2017) Social capital and community resilience in coping with flood disasters in Malaysia. In: E-proceedings of the 37th IAHR world congress, Kuala Lumpur, Malaysia, 13-18 Aug 
6. Azuhan M (2015) Kelantan flood-divine vs. anthropogenic causes. In: Proceedings of national geoscience conference, Kota Bharu, Geological Society of Malaysia, pp 2-5, 31 July-1 Aug

7. Ismail MGH, Chan NW, Zakaria NA, Ghani AA (2015) A review of standard operating procedures (sop) used in flood relief operations during the December 2014 flood in Pahang. In: Proceedings Transformasi Sosial 2015. Fakulti Kemanusiaan, Seni \& Warisan Universiti Malaysia Sabah, pp 18-27

8. Chan NW, Tan ML, Ghani AA, Zakaria NA (2019) Sustainable urban drainage as a viable measure of coping with heat and floods due to climate change. In: IOP conference series: earth environmental science

9. Ghani AA, Chang CK, Leow CS, Zakaria NA (2012) Sungai pahang digital flood mapping: 2007 flood. Int J River Basin Manage 10(2):139-148

10. Chan NW (2019) Sustainable urban drainage as a viable measure of coping with heat and floods due to climate change. In: 9th international conference on future environment and energy (ICFEE 2019)

11. Drdácký M, Sližková Z (2012) Structural strategies and measures reducing flood action on architectural heritage. Risk Anal VIII:249-260

12. Kelman I, Rauken T (2012) The paradigm of structural engineering approaches for river flood risk reduction in Norway. Area 44(2):144-151

13. Singkran N (2017) Flood risk management in Thailand: shifting from a passive to a progressive paradigm. Int J Disaster Risk Reduct 25:92-100

14. Jamrussri S, Toda Y (2017) Simulating past severe flood events to evaluate the effectiveness of nonstructural flood countermeasures in the upper Chao Phraya River Basin, Thailand. J Hydrol Reg Stud 10(2017):82-94

15. Chan NW, Parker DJ (1996) Response to dynamic flood hazard factors in Peninsular Malaysia. Geog J 162(3):313-325

16. Mohita MA, Sellub GM (2013) Mitigation of climate change effects through non-structural flood disaster management in Pekan Town, Malaysia. Procedia—Soc Behav Sci 85:564-573

17. Sinnakaudan SK, Ghani AA, Ahmad MSS, Zakaria NA (2003) Flood risk mapping for Pari River incorporating sediment transport. Environ Modell Software 18(2):119-130

18. Chan NW, Samat N, Lee LK, Ghani AA (2015) Role of citizen science in responding to flood disasters: a case study from Malaysia. In: Proceedings of the international conference on "towards urban water security in Southeast Asia: managing the risks of extreme events", Phnom Penh, Asian Institute of Technology, pp 227-238

19. Chan NW, Roy R, Lai CH, Tan ML (2018) Social capital as a vital resource in flood disaster recovery in Malaysia. Int J Water Resour Dev

20. Hussaini A (2014) A comprehensive urban stormwater management approach in combating flood in Malaysia: an indispensable link for safer, greener and more livable urban environment. In: 13th international conference on urban drainage

21. Mahmud MA, Samat N, Noor NM (2016) Identifying factors influencing urban spatial growth for the George Town Conurbation. Plann Malaysia 14

22. Chan NW (2002) Flood hazards and disasters in Malaysia: causes, impacts and solutions with respect to river floods. Rivers: towards sustainable development. Penerbit Universiti Sains Malaysia, Penang, pp 114-127

23. Ghani AA, Zakaria NA, Abdullah R, Yusoff MF, Sidek LM, Kassim AH, Ainan A (2004) Bio-ecological drainage systems (bioecods): concept, design and construction. In: International conference "ICHE 2004 - the sixth international conference on hydro-science and engineering"

24. Zakaria NA, Ghani AA, Abdullah R, Sidek LM, Kassim AH, Ainan A (2004) MSMA - a new urban stormwater management manual for Malaysia. Paper presented in international conference "ICHE 2004 - the sixth international conference on hydro-science and engineering”, Brisbane, 30 May-3 June 2004

25. Kannapiran RKM (2005) A study and evaluation on SMART project, Malaysia. Unpublished dissertation, Course ENG4111 and 4112 Research Project, Bachelor of Engineering (Civil Engineering), University of Southern Queensland, October 2005 
26. Magilligan FJ, Nislow KH (2005) Changes in hydrologic regime by dams. Geomorphology 71(1):61-78

27. Ismail $N$ (2014) Issues and problems towards the sustainable dam management system in Malaysia. Int J Innovation Manage Technol 5(6):406-411

28. Albayati MMA (2014) Prediction of sediment inflow to Kenyir reservoir using combined modeling. Aust J Basic Appl Sci 8(17):33-44

29. Abidin Z (2006) Overview of dam safety in Malaysia. Jurutera: 22-23

30. Rokiah TP, Hussain S, Rahim A, Nor M, Ismail H (2014) The level of satisfaction towards flood management system in Kelantan, Malaysia. Pertanika J Soc Sci Humanit 22(1):257-269

31. Starosolszky Ö (1994) Chapter 31: flood control by levees. In: Rossi G, Harmancioğlu N, Yevjevich V (eds) Coping with floods. NATO ASI series (series E: applied sciences), vol 257. Springer, Dordrecht, pp 617-635

32. Rosenberg M (2019) How the Netherlands reclaimed land from the sea. ThoughtCo, 2 Jan 2019. https://www.thoughtco.com/polders-and-dikes-of-the-netherlands

33. Kundzewicz ZW (2002) Non-structural flood protection and sustainability. Water Int 27(1): $3-13$

34. Abdullah HK (2002) Integrated river basin management. "Rivers: towards sustainable development". Penerbit Universiti Sains Malaysia, Penang, pp 3-14

35. Augustine R (2016) Deforestation the main cause of flooding. FMT News 